\title{
How to Make Them Hear: Challenging Transnational Oil Interests in Ecuador's Amazon Region
}

\author{
Malcolm Rogge
}

\begin{abstract}
This article discusses how oil develop. ment in the Amazon basin of Ecuador threatens to displace indigenous peoples through environmental contamination and colonization. It presents approaches to capacity-building for indigenous and mestizo-settler communities to deal with threats to human rights and the environment due to oil development. While the focus is on transnational oil operations in the Ecuadorian Oriente, many of the issues and empowerment methods discussed here are transferable to other local/global conflicts around the world, especially where indigenous and peasant communities are adversely affected by transnational resource extrac tion activities (mining, forestry, and oil).
\end{abstract}

\section{Précis}

Le présent article montre en quoi le développement pétrolier du bassin de l'Amazone équatorienne menace d'entraîner le déplacement des populations indigènes de par la contamination et la colonisation. On présente les différentes approches de la mise en place d'une capacité de résistance, chez les communautés indigènes et de colons mestizo, leur permettant de faire face à la menace dont les droits humains et les conditions environnementales font l'objet à cause du développement pétrolier. Le point de mire de l'argumentation concerne iciles opérations pétrolières transnationales dans l'Oriente équatorien. Cependant un bon nombre des questions et des procédures d'appropriation de pouvoir discutées ici sont applicables à d'autres conflits globaux et/ou locaux ailleurs au monde, surtout là où des communautés indigènes et paysannes sont affectées

Malcolm Rogge is Graduate Student, combined program MES and LLB, York University, Toronto. négativement par des activités transnationales d'extraction de matières premières (mines, forêts, pétrole).

\section{Introduction}

One of the many adverse social impacts of oil development in the Andean-Amazon countries is the internal displacement of indigenous peoples from their traditional territories. In the Ecuadorian Amazon region known as the "Oriente," 23 years of oil development has resulted in the gradual dispersion and displacement of several groups of indigenous peoples. Many of the ancestral indigenous territories in the region have, quite literally, become oil fields. The social and economic impact of oil development and colonization on indigenous peoples and their displacement have been well-documented by various human rights and environmental organizations (CESR 1994; Grylls 1992; Kimmerling 1991). The purpose of this article is not to recite the litany about how oil operations can adversely affect the lives of local people. Rather, I hope to contribute to the development of a constructive approach to assisting local communities in defending their environmental human rights.

The link between human rights and environmental issues is abundantly clear to indigenous peoples and mestizo settlers living in the Oriente. Basic social and economic rights have been eroded due to environmental contamination resulting from the widespread use of substandard and ultra-hazardous oil extraction technologies. Throughout the Oriente, indigenous leaders, local organizers, human rights activists, and environmental activists acknowledge the need for local-level capacitación, or "capacity-building." For many community leaders and activists capacity-building is viewed as the remedy for local people who have been, or are threatened to be, left in the wake of the ever-expanding oil industry. In this article, I outline some issues and approaches to human rights and environmental capacity-building for indigenous and mestizo settler communities adversely affected by oil development. While the focus is on transnational oil operations in the Oriente, many of the issues and methods discussed here are transferable to other local/global conflicts around the world, especially where indigenous and peasant communities are adversely affected by transnational resource extraction activities (mining, forestry, and oil).

\section{Indigenous Peoples and Oil Development in the Oriente}

Approximately 198,000 indigenous people live in the Oriente, comprising eight distinct nationalities: the Secoya, Siona, Cofan, Huaorani, Shuar-Achuar, Quichua, Shiwiar, and Zaparos. Oil development has dramatically impacted the lives of all of these groups. As oil operations expanded, previously inaccessible areas of the Oriente became open for settlement. Largescale migration of mestizo settlers occurred during the oil boom of the 1970 s, when over 250,000 poor farmers from the more densely populated coastal and Sierra regions moved to the Oriente. Repeating a pattern of events that has occurred throughout the Amazon basin, poor mestizo settlers cut down forests to establish cattleranches. In 1982, the annual population growth rate for the Oriente was 4.9 percent; and in areas where oil production was more concentrated the growth rate reached 8 percent (Grylls 1992, 12). These areas are characterized by extreme poverty and low levels of human development (Larrea 1992, 115). Needless to say, the rapid influx of mestizo settlers had a detrimental im- 
pact on the lives of indigenous people, and thousands of indigenous peoples were dispersed from their ancestral territories. Ironically, even mestizo settlers, who were originally encouraged to migrate from the coast to the oil producing areas, have seen their social and economic conditions deteriorate because of oil contamination.

Since petroleum operations began in the Oriente, the Secoya and Siona nations have been dispersed by outmigration and assimilation-only about 500 Secoya and Sionas remain in their traditional territories. About 15,000 Cofan once lived in the Oriente, but after twenty years of the petroleum operations in their territory, only a few hundred Cofan retain their traditions and languages. Today, the Huaorani people number approximately 1500 , though at one time, tens of thousands of Huaorani inhabited the region (Grylls 1992, 40). The dispersion of these peoples almost certainly means the extinction of their cultures, languages, and the loss of their orally transmitted knowledge-base.

The adverse social impact of oil operations on indigenous peoples is viewed by many Ecuadorians as an unfortunate, but unavoidable cost of economic development. Indigenous and settler communities are up against an industrial oligarchy that clearly supports an urban-biased, export-oriented development paradigm. For almost thirty years, oil development has been a national economic priority. Most of the oil produced is exported because the government desperately needs foreign currency to service massive debts. The maintenance and expansion of oil-related infrastructure is supported by loans from the multilateral lending agencies, and through bilateral aid programs (including oil-industry aid from Canada). Subsurface mineral rights are held by the State. The adverse social and environmental costs of the surface activities related to oil development are largely invisible to the distant urban beneficiaries of industrial development. The needs and interests of local groups, especially indigenous peoples, are vir- tually ignored in all stages of the planning and implementation of oil development activity.

From 1964 to 1989, petroleum activity in Ecuador was centered primarily in the northeast Oriente and was undertaken exclusively by the Texpet consortium (Texaco and Petroecuador). Beginning in 1989, the Ecuadorian government opened much of the remaining Oriente to the world's oil companies. Dozens of transnational oil companies moved into concession blocks that used to be remote areas populated almost exclusively by indigenous peoples. The borders of these concession areas have no correspondence to the social and political reality of the indigenous peoples who live there. For instance, in August 1991, Occidental Corporation won a twentyyear concessionary interest in a 200,000 hectare area called "Block 15" -an area that extends arbitrarily across parts of the traditional and legally recognized territory of the Secoya and Siona. Occidental estimates petroleum reserves within Block 15 at approximately 225 million barrels, which is enough to supply the U.S. domestic demand for a fairly significant period of time: 12.7 days. In July 1996, Occidental offered the Siona and Secoya peoples in Block 15 little more than medicine chests and water pumps in exchange for undefined access to the oil and gas reserves below the ground. An "agreement" was reached between company officials and four SionaSecoya leaders, but it was later repudiated by the Siona-Secoya on the grounds of unconscionability, duress, and misrepresentation. ${ }^{1}$

The Siona and Secoya are dependent for their subsistence on hunting, fishing, the management of forest products, and agriculture. The environmentalimpact of the surface oil and gas activity will very likely result in the gradual erosion of their subsistence economy. In a few years time, the Siona and Secoya may be forced to leave their traditional lands in search of employment or other means of satisfying their basic needs. Such a forced migration and dispersion will almost certainly result in the extinction of the SionaSecoya as a distinct people. ${ }^{2}$

Recent attempts at land reform have not succeeded in helping resolve land use disputes over indigenous territory; rather, the existing land reform mechanisms further entrench in law the State's oil and mineral development priorities. After national indigenous uprisings in the early 1990s, the Ecuadorian government granted ancestral land titles to many indigenous groups in the Oriente and elsewhere in Ecuador. However, these land titles do not adequately protect indigenous communities from oil activity, as they expressly prohibit local people from "impeding" or "obstructing" oil and mining operations.

\section{The Challenge to Local Communities}

Local indigenous and mestizo settler organizations are at an extreme political, legal, and institutional disadvantage as compared to the global interests that move quickly into their communities. Prior to the commencement of Texpet's operations in the 1960s, Amazonian indigenous communities and their representative organizations did not have to deal with transnational oil corporations as part of their daily reality. Today, both indigenous and settler organizations must react continuously to the activities of the ever-increasing number of transnational petroleum operators in the Oriente region. Leaders face rapid changes in their "external relations," and must respond to new and conflicting demands from the people they represent. They suddenly find that they need to travel to distant towns and even cities to seek advice about issues related to oil development.

While the TNC's operate swiftly under the direction of a vertically organized international hierarchy, local communities are often thrown into a chaotic disarray, particularly when different members of the community jockey for their individual interests. At the village level, decision-making can be very time-consuming and ineffectual as short-term interests are often 
widely divergent. Unity of voice at the local level can be very difficult to achieve in the short term-this creates a strategic window of opportunity for resource extraction companies which can move swiftly and which are governed by very narrow interests. The TNC's are able to take advantage of the confusion at the community level by consolidating operations before local communities can organize an effective opposition.

One of the main reasons transnational oil companies can pursue "accelerated development" in countries like Ecuador is because local communities have little or no access to politi$\mathrm{cal}$ or legal representation. It is hardly an exaggeration to state that where local populations do not have political power, adequate legal protection of their lands, or cannot access legal services, oil companies are free to operate much as though the areas were uninhabited. Where the members of local organizations donot have the practical skills or resources needed for effective participation in environmental planning and management, oil companies are spared the "costs" of local-level democracy. Human rights and environmental capacity-building in the Oriente is aimed at raising the "reduced overhead and operating costs" that are associated with extracting oil where people have little or no access to legal services, the political process, or the resources needed to challenge the oil agenda.

\section{Methods and Approaches to Human- Rights and Environmental Capacity-building}

Capacity-building on environmental human rights aims to equalize, through the transfer of knowledge and skills, the power-imbalance of local communities and global oil interests; it is the name given a process that involves local people developing the skills they require to defend their rights and long-term interests as peoples and communities. Capacitybuilding contributes to the development of the organizational, political, technical, and legal skills that local communities and their leaders require to influence oil companies, governments, and other oil-related stakeholders. Non-governmental organizations, such as indigenous organizations, environmental organizations, and human rights groups, are currently involved in assisting local Ecuadorian communities develop the necessary skills to defend their legitimate rights and interests.

One of the challenges of capacitybuilding in the areas of human rights and the environment is to communicate legal and technical issues in a such way that local people are empowered and not further alienated. Much work needs to be done to develop techniques for popular legal and human-rights education focusing on environmental justice issues. One obvious approach to is to work directly with local people to determine the consequences in daily-life of environmental degradation caused by oil operations. In this approach, local people are asked to consider, in practical terms, how they will meet basic needs if oil contamination has an effect on local subsistence activity. In answering this question, communities must consider in concrete terms how oil operations will affect their livelihoods. At the same time, in abstract terms, the communities contemplate how oil operations have the potential to violate their social and economic rights.

Popular human rights and environmental facilitators should be committed to understanding how local people manage the resources they depend upon to meet basic needs. Facilitators must understand and respect the local knowledge systems and local resource management practices. To communicate effectively about legal and human rights with indigenous and settler communities, facilitators should be able to integrate discussions of shelter, food, nutrition, water management, waste-management, agriculture and hunting, health, knowledge and uses of plants and trees, and other local resource management practices into their discussions about the legal and human rights aspects of oil operations.
The daily satisfaction of basic needs is the concrete problem to which abstract legal and rights discourse can be applied. In using examples from the immediate experiences of the people he or she is working with, the facilitator is able to construct a culturally relevant interpretation of human and legal rights.

One approach for a facilitator is to work with community members to systematically consider risks to the community when resources are destroyed through the contamination of soil, drinking water and rivers, and noise contamination. For example, communities that are dependent on their forest for key building materials-such as hard-woods used for specific construction purposes-should consider how they will build their homes if they are forced to leave the forest, or if important natural construction materials are destroyed because of deforestation.

\section{Capacity-building Workshops on Human Rights and the Environment}

I have outlined below the main theme areas that may be covered in capacitybuilding workshops of this nature. The list is not inclusive, nor does it indicate a sequence that should be followed, but is meant to suggest the range and content of capacity-building activities as they relate to oil development.

Who are the stakeholders? - the various political, corporate, and community interests in oil operations (stakeholders may include: women, elders, youth, men, other indigenous groups, oil companies, oil company employees, the government, international organizations, environmental organizations, etc.).

How to influence stakeholders? - the different approaches required when communicating with different stakeholders, for example, how other indigenous communities should be approached differently than oil company officials, or the government. 
The political economy of oil-the political and economic forces that drive oil production in Ecuador in general, and in the specific communities adversely affected by oil operations; the relationship between Ecuador's external debt and oil export; the history of oil activity in the region.

Car-culture and energy consumption in the North-energy-use and consumption of resources in the industrialized countries.

Why do transnational oil companies come to Ecuadorian Amazonia? - transnational corporations and how they benefit from operating in Ecuadorian Amazonia.

Company-specific information-information about the company operating in the participants' community, including how to contact company officials in Ecuador and at the company headquarters; the different standards that transnational oil companies must abide by in different countries.

Finding the information needed to make decisions-the practical tasks in finding information; accessing information from the government or the company; difficulties.

What are property titles?-property rights and land titles.

Workers' rights and workplace health and safety-intended for communities which expect that the oil companies will provide jobs.

Environmental law in Ecuador-what environmental laws are for, how they are enforced, and the international environmental laws that the Ecuadorian government must respect.

The right to organize and inform the community - the right to gather information and the right to freedom of association.

Human rights-human rights monitoring; how to use human rights discourse as part of an overall strategy to put pressure on the government or the company.

Responsibilities and obligations of oil companies-overview of the major responsibilities of corporations with respect to environmental and social issues.

Administrative, criminal, and international procedures for making claims against oil companies-the use and limitations of the legal system to defend the legal rights of communities and individuals.

How to organize an environmental monitoring committee-dedicated to monitoring the effects of oil activity in the area.

Environmental and social impact of oil activity-the potential environmental and social impacts of oil operations, including: the introduction of diseases, community chaos and division, subversion of leaders, changes in traditional diet, foods, loss of language, loss of territories, loss of traditional knowledge, sudden immersion in a foreign economic system, extinction of species, etc.

Alternative development strategiesother possibilities for local economic development, e.g. ecotourism; how to use alternative development plans as leverage in discussions with company and government officials.

Map-reading and counter-mapping-basic familiarity with map-reading; community counter-mapping by making their own maps of their settlements and traditional lands; can be used to show company and government officials how local communities use and depend on the natural resources around them.

Negotiations-what negotiations are for, how to conduct one, and how to know when a "negotiation" has already happened.

Models of agreements between communities and oil companies-analyze and critique agreements already reached in other communities.

Organizing workshops and discussions in your own community-how to continue the capacity-building process independently.

Company strategies in business and negotiation-company-community-relations strategies; strategies of economic coercion.
Forging alliances with other organizations and communities-ideas and plans.

\section{The Need for Human-Rights and Environmental Capacity-building in Relation to Oil Production}

A great need for oil-development-related human rights and environmental capacity-building already exists in the Oriente; this need will intensify as oil operations expand in Ecuador. Moreover, capacity-building activities will be needed in Peru, Columbia, and Bolivia as oil activity expands throughout the western Amazon region. Every major oil company in the world is operating in Latin America: Shell and Mobil operate in Peru (in concession areas covering over 2 million hectares); British Petroleum operates in Colombia; Occidental operates in Ecuador and Peru. There are also dozens of "fly-by-night". operations working throughout Latin America. The various transnational interests compete for concession areas located in often very remote parts of the continent-areas where indigenous people have had little contact with outsiders. The hope is that through local human-rights and environmental capacity-building, transnational oil companies will feel more pressured to respect the environmental and social rights of the local people.

At the local level, human-rights and environmental capacity-building activities are aimed at providing training to local organizations that have expressed a need for advice on how to communicate with government officials, the media, and company officials. When local communities are aware of their rights in Ecuadorian law and their human rights in international law, they are able to more clearly articulate demands to their governments and the oil companies.

Local indigenous and mestizo settler organizations in the Oriente consistently speak of the need for capacity-building. They recognize, in no uncertain terms, the need tobecome more proficient in the legal and technical discourses that the oil companies and national government engage in. 
Capacity-building requires the cooperation of indigenous leaders, communities, NGO's, settler organizations, environmentalists, and human-rights workers. The aim of their activities must be to improve the capacity of local indigenous and settler organizations to influence government development policy, legislation, and resource management practices. This is necessary in order to protect lands, farms, resources, cultures, and means to satisfy basic needs. Future study might demonstrate the extent of population displacement due to oil operations over the long term and the contribution oflocalhuman-rights and environmental capacity-building to an overall reduction in such displacement. II

\section{Reports}

Somali Refugees in Toronto: A Profile

By Edward Opoku-Dapaah

ISBN 1-55014-278-x, 130 pp., \$12.95.

This report examines the social, residential, and linguistic characteristic of Somali refugees, their participation in the local economy, and the activity of Somali com munity organizations. The report also contains valuable suggestions and recommen dations concerning suitable and more efficient service delivery to this community.

Cambodian Refugees in Ontario: An Evaluation of Resettlement and Adaptation By Janet Mclellan

ISBN 1-55014-267-4, 142 pp., \$12.95 This major study examines the effects of various forms of sponsorship on Cambodian resettlement. It also focuses and the linguistic, economic, educational, training and social dimensions of the whole process of adaptation. The delivery of services by governmental and NGO agencies as well as the effects of the past traumatic experiences of genocide and mass starvation on Cambodian refugees are fully discussed.

\section{Notes}

1. My own research, Quito, June 1996

2. Personal communication with Humbert

Piyajvaje, President, OISE, San Pablo,

Ecuador, August 2,1996.

\section{References}

Benjamin, C. S., and T. Turner. 1993. "Playing Out a Full Hand: Indigenous Peoples' Movements and the Vulnerability of Transnational Energy Corporations." of Transnational Energy Corporations."
International Seminar on Indigenous PeoInternational Semi
ple, Kuala Lumpur

Bryant, R. 1992. "Political Ecology: An Emergin Research Agenda in Third World Studies." Political Geography 11, no. 1, 13-14

Centre for Economic and Social Rights (CESR) 1992. Rights Violations in Ecuadorian Amazonia New York: CESR.

Freire, P. 1994. Pedagogy of the Oppressed. New York: Continuum.
Freire, P., and Ira Shor. 1987. A Pedagogy For Liberation. New York: Bergin \& Garvey.

Granda, A., and Natalie Pierce. 1995, Los Derechos de Las Poblaciones Amazonicas Frente a La Activida Petrom: Guta para la Accion Qu La Actividad Petrolera: Guta para la Accion. Quito:
Acci6n Ecol6gica.

Grylls, C. 1992. Environmental Hooliganism in Ecuador. Oslo: Framtindenl V Are Hender.

Kimmerling, J. 1991. Amazon Crude. New York: National Resource Defence Coun cil.

Larrea, C. 1992. "The Mirage of Oil Development: Oil, Employment, and Poverty in Ecuador (19721990)." PhD thesis, York University, Toronto.

Schuler, M., and Sakuntala KadirgamarRajasingham. 1992. Legal Literacy: A Tool for Women's Empowerment New York: UNIFEM.

Toshiyuko Drury, R., and Flora Chu. 1994. "From White Knight Lawyers toCommunity Organizing." Race, Poverty and the Environment (Fall 1994/Winter 1995). CJ

\section{Refugee Rights Report on a Comparative Survey}

By

James C. Hathaway and John A. Dent

Toronto: York Lanes Press, 1995, pp. 82. \$11.95 ISBN 1-55014-266-6

Are visa controls intended to keep refugees from reaching an asylum country legal? Can asylum-seekers legitimately contest conditions of detention? At what point do refugees have the right to work, or to claim social assistance?

These are among the many issues addressed by Refugee Rights: Report on a Comparative Survey, a ground-breaking analysis of the human rights of refugees around the world. Working in collaboration with thirty renowned legal experts from Europe, Africa, Asia, Oceania, North America, and Latin America, Professor James Hathaway, Osgoode Hall Law School, York University, and John Dent, Refugee Law Unit, Centre for Refugee Studies, York University, analyze the international legal instruments that set the human rights of refugees. By grounding their analysis in real-life challenges facing refugees today, Hathaway and Dent have produced a book as valuable to activists as to scholars.

Refugee Rights will provoke debate on the adequacy of the international refugee rights regime. It is essential reading for everyone concerned to counter threats to the human dignity of refugees.

Available from:

Centre for Refuge Studies, York University

Suite 333, York Lanes, 4700 Keele St., North York ON M3J 1P3

Fax: (416) 736-5837· Email: refuge@yorku.ca 